\title{
Factors on Learning Satisfaction with a Focus on E-learning in the Military
}

\author{
Yang-Ha Chun
}

\begin{abstract}
The Department of National Defense in South Korea is taking steps to develop smart learning to prepare for the information age, but as of yet there have not been any sufficient empirical analyses on learning satisfaction. The Department of National Defense in South Korea is taking steps to develop smart learning to prepare for the information age, but as of yet there have not been any sufficient empirical analyses on learning satisfaction. The findings of this study showed the following factors as positively affecting learning satisfaction with e-learning in the military: learning motivation, ease of the use environment, learning support level of the organization, content feasibility, and instructor-learner interaction. Similarly with the official education centers and universities, learning motivation was proven to be the most important factor in e-learning education in the military. Also, as factors that reflect the nature of the military, ease of the use environment and learning support level of the organization were identified as factors that affect learning satisfaction. This result suggests the importance of the infrastructure and setting for e-learning in the military. The factors of content feasibility and infrastructure-learner interaction were also shown to affect learning satisfaction. Suggesting further investment in the design and development of e-learning contents and an increased proactiveness of the instructors to improve learning satisfaction.
\end{abstract}

Keywords : e-learning, Higher education, Satisfaction of learning

\section{INTRODUCTION}

ICT is ICT is used in almost all fields to gain supremacy in modern warfare, which is also defined as network-centric warfare. The systems for contents, simulators, simulation, and e-learning (distance education) have been built and used in the field of education to facilitate learning anytime and anywhere. Many empirical studies on learning satisfaction with e-learning have been conducted on universities and corporations, but less on the educational institutions in the military.

The purpose and scope of this study is to present a study model and hypotheses on the factors affecting learning satisfaction with e-learning through a theoretical background survey, and to analyze the surveys to empirically examine the factors affecting learning satisfaction with e-learning in the military.

Learning is an active process of building knowledge and skills through practice within a supportive community. Online or electronic learning(e-learning) environments offer the possibilities for communication, interaction and multimedia material delivery that enhance learner-directed learning [1, 2].

Revised Manuscript Received on September 25, 2019

Yang-Ha Chun, Dept. of Computer Science, Yongin University, Gyeonggi-do, Republic of Korea. Email: yangha00@yongin.ac.kr e-learning refers to web-based learning provided in an online environment to instruct and develop necessary expertise, techniques and appropriate value system for the profession. e-learning may be identified as having the following properties: no restrictions with regard to time or space; individualized learning; self-directed learning; compatible platforms; and formation of a learning community. E-learning success can be defined through multiple perspectives. One way to define success is through outcome factors such as enhanced learning, time savings, and academic success $[3,4]$.

Unlike in the civilian sector, e-learning education in the military has some restrictions with regard to time and space and a variety of operating environments and conditions, depending on the education institute. As such, the findings of studies on the civilian sector should not be indiscriminately adopted in military applications.

\section{MATERIALS AND METHODS}

The subjects are the educational institutes in the military of South Korea. The survey method was used for hypothesis testing. SPSS Ver. 18 was used for the Cronbach's alpha analysis and inter-variable correlation analysis to confirm the confidence of the measuring instrument on each subfactor The contributions of this study are as follows: first, it verifies the factors affecting satisfaction with e-learning in the military, an area in which studies have been scarcer than in the civilian sector; second, it proposes improvements to promote the educational effects of e-learning in the military.

\section{A. Technology Acceptance Model}

Proposed by Davis, the TAM (Technology Acceptance Model) Figure 1 shows the impact of perceived usefulness and perceived ease of use on the user's attitude toward using and behavioral intentions to use based on the rational behavioral theory. The model has been widely studied in the ICT field [5,6]. In addition, the model is used to analyze the learning effects and factors of learning satisfaction.

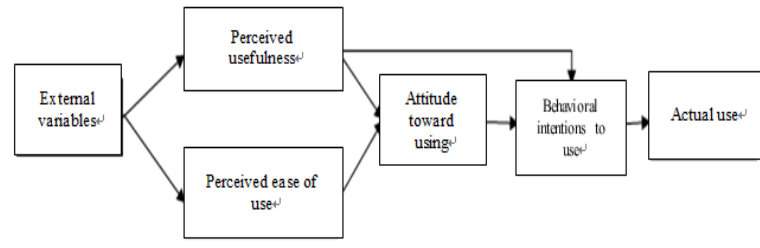

Fig. 1. Technology Acceptance Model (TAM)

\section{B. Factors affecting learning satisfaction}

Learning satisfaction can be defined as the accomplishment of the learning objectives or the

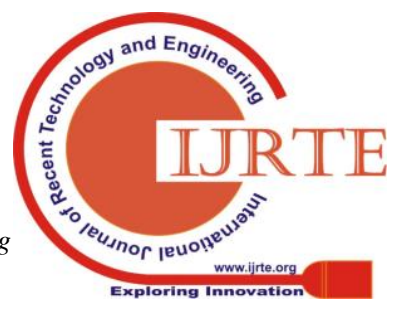


"state of mind when the individual expectation of the learner has been met" after the learning [7, 8]. Park Seong-yeong classified the factors affecting learning satisfaction as the learner, the learning environment, and the content design [5]. The satisfaction of the learner is inevitable for successful implementation of e-learning environment. Satisfaction is widely accepted as a desirable outcome of any product or service experience and is the most explored construct in the history of marketing scholarship. Generally, satisfaction is a factor used to monitor the product or service quality and also to predict customer loyalty and other behavioral consequences [9].

This study supplements some of the verified measuring instruments to set the following as the 'learner' determinants to examine the factors affecting learning satisfaction in the military: learning motivation, proactive learning attitude, and internet usage level. As the determinants of the 'learning environment' ease of the use environment and learning support level of the organization were selected. Meanwhile, content feasibility and instructor-learner interactions were set as the determinants of 'instructional design' [4].

\section{Factors affecting learning satisfaction}

Since e-learning the three categories of learner, learning environment, and instructional design are strongly tied to ICT, students' satisfaction is an important outcome of e-learning[10].

This study structured the study model with reference to Figure 2 with the factors proposed from preceding studies to examine the factors affecting e-learning in the military. The following seven factors were proposed as factors affecting learning satisfaction: learning motivation, proactive learning attitudes, internet usage level, ease of the use environment, learning support level of the organization, content feasibility and instructor-learner interactions. These were organized under the three categories of learner, learning environment, and instructional design.

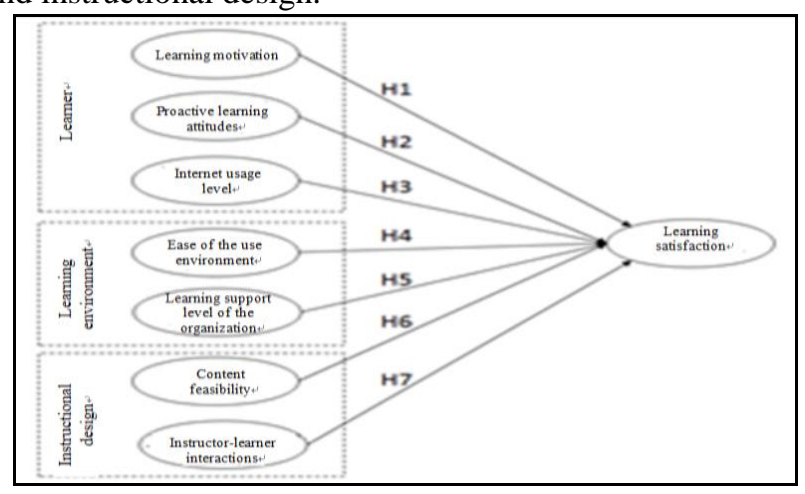

Fig. 2. Study Model

The hypotheses that the study model attempts to verify are as follows:

H1: The learning motivation of the learner will positively (+) affect learning satisfaction.

$\mathrm{H} 2$ : The proactive learning attitudes of the learner will positively (+) affect learning satisfaction.

H3: The learner's level of internet usage will positively $(+)$ affect learning satisfaction.

H4: The ease of the e-learning use environment will positively (+) affect learning satisfaction.
H5: The learning support level of the organization will positively (+) affect learning satisfaction.

H6: The feasibility of the education content will positively (+) affect learning satisfaction.

H7: The instructor-learner interaction will positively $(+)$ affect learning satisfaction.

\section{Research Method}

The questionnaire for this study uses a 5-point scale. To enhance the confidence in the study and change the subject of the survey, some of the questions used by Park Seon-ok [5] were modified and revised for the military. The survey consisted of a total of 48 questions, covering the categories of learner, learning environment and instructional design, as shown in Table 1.

To examine the factors affecting the learning satisfaction with e-learning in the military, a survey was conducted on system operators, instructors and learners (including learners who had completed a course) in three schools, including 00 school, as some of the military education institutions. 300 copies of the questionnaire were distributed on paper, and 290 copies were collected. Of these, a total of 278 copies were used for the analysis, once 12 copies that were either incomplete or erroneous were excluded.

Table- I: Name of the Table that justify the values

\begin{tabular}{|c|c|c|c|c|}
\hline \multicolumn{2}{|c|}{ Classification } & \multirow{2}{*}{$\begin{array}{c}\text { Factor } \\
\begin{array}{c}\text { Learning } \\
\text { motivation }\end{array}\end{array}$} & \multirow{2}{*}{$\begin{array}{c}\text { No. } \\
\text { of } \\
\text { Q. }\end{array}$} & \multirow{2}{*}{$\begin{array}{c}\text { Cronbach } \\
\alpha \\
\text { coefficie } \\
\text { nt } \\
0.900\end{array}$} \\
\hline \multirow{7}{*}{$\begin{array}{l}\text { Indepen } \\
\text { dent } \\
\text { Variable }\end{array}$} & \multirow{3}{*}{ Learner } & & & \\
\hline & & $\begin{array}{l}\text { Proactive } \\
\text { learning } \\
\text { attitudes }\end{array}$ & 5 & 0.711 \\
\hline & & $\begin{array}{l}\text { Internet usage } \\
\text { level }\end{array}$ & 1 & - \\
\hline & \multirow{2}{*}{$\begin{array}{c}\text { Learning } \\
\text { environm } \\
\text { ent }\end{array}$} & $\begin{array}{c}\text { Ease of use } \\
\text { environment }\end{array}$ & 6 & 0.830 \\
\hline & & $\begin{array}{c}\text { Learning } \\
\text { support level of } \\
\text { the organization }\end{array}$ & 5 & 0.647 \\
\hline & \multirow{2}{*}{$\begin{array}{c}\text { Instructio } \\
\text { nal } \\
\text { Design }\end{array}$} & $\begin{array}{c}\text { Content } \\
\text { feasibility }\end{array}$ & 5 & 0.905 \\
\hline & & $\begin{array}{c}\text { Instructor-learn } \\
\text { er } \\
\text { interaction }\end{array}$ & 6 & 0.925 \\
\hline \multicolumn{2}{|c|}{ Dependent variable } & $\begin{array}{l}\text { Learning } \\
\text { satisfaction }\end{array}$ & 7 & 0.948 \\
\hline \multicolumn{3}{|c|}{ Demographic variables } & 6 & - \\
\hline \multicolumn{3}{|c|}{$\begin{array}{c}\text { Cyber courses, internet usage time, learning } \\
\text { time }\end{array}$} & 3 & - \\
\hline
\end{tabular}

\section{RESULTS AND DISCUSSION}

This journal uses double-blind review process, which means that both the reviewer (s) and author (s) identities concealed from the reviewers, and vice versa, throughout the review process. All submitted manuscripts are reviewed by three reviewer one from India and rest two from overseas. There should be proper comments of the reviewers for the purpose of acceptance/ rejection. There should be minimum 01 to 02 week time window for it. 


\section{A. Hypothesis verification results}

Prior to the multiple regression analysis, which was performed to examine the factors affecting learning satisfaction with military cyber education as the research objective, the inter-variable correlations included in the study model were analyzed as shown in Table 2. Among the independent variables, the correlation was strongest between 'content feasibility' and 'instructor-learner interaction' at 0.685 , and weakest between 'learning support level of the organization' and 'internet usage level' at 0.100. Some independent variables were correlated by 0.5 or above, but 22 of the 28 correlations $(78.57 \%$ ) were 0.5 or below and the tolerance limit of all independent variables was 0.1 or above, showing no problem with multi-collinearity.

The correlations among variables other than learning satisfaction were all positive. The correlations among learning motivation, ease of the use environment, learning support level of the organization, content feasibility, and instructor-learner interactions were strong at 0.6 or above. In the study by Park Seon-ok on the Central Officials Training Institute the correlation between content feasibility and learning satisfaction was highest, whereas the present study found the strongest correlation was between instructor-learner interaction and learning satisfaction. This signifies that learners in the education institutes in the military consider the role of the instructor to be important.

Table 3 shows the results of the regression analysis. The dependent variables include learning motivation, proactive learning attitude, internet usage level, ease of the use environment, learning support level of the organization, content feasibility, instructor-learner interaction, e-learning time, age group, education level and years of service.

$\mathrm{R} 2$ of the regression analysis is 0.714 . The variables included in the model explain at least $70 \%$ of the changes in the dependent variables. The F-value was 60.471 , which is significant with a significance level of 0.01 . This study revealed that learning motivation, ease of the use environment, learning support level of the organization, content feasibility, and instructor-learner interaction are the factors affecting learning satisfaction.

In the end, the following hypotheses were accepted: H1, H4, H5, H6, and H7. The following hypotheses were rejected: $\mathrm{H} 2$ and $\mathrm{H} 3$.

\section{B. Analytical result analysis}

The standardized regression coefficient of learning motivation was 0.178 . The $\mathrm{t}$ value was 4.030 , which is significant with a significance level at 0.01 . Strong learning motivation positively (+) affected the learning satisfaction with e-learning in the military.

The regression coefficient of proactive learning attitude was -0.006 with a $\mathrm{t}$-value of -0.153 , which is not significant with a significance level of 0.05 .

The regression coefficient of internet usage level was 0.047 , with the t-value of 1.321 , which was not significant with a significance level at 0.05 .

The regression coefficient of ease of the use environment was 0.110 , with the t-value of 2.410 , which is a statistically significant impact on learning satisfaction at a significance level of 0.05. Demonstrating that the e-learning environment in the military contributed to learning satisfaction. These findings also reflect a restriction on e-learning in the military with the intranet being alternated between military duties, in contrast to the free internet environment, calling for the need for improvements in the e-learning system.

The regression coefficient of the learning support level of the organization was 0.149 , with a t-value of 3.335 , which is a statistically significant effect on learning satisfaction at the significance level at 0.01. Suggesting the need for more consideration for time and duties for the learners to take e-learning in the military.

The regression coefficient of content feasibility, as a component of instructional design, was 0.125 , with the t-value of 2.592 at the significance level at 0.01 . This factor was shown to positively affect learning satisfaction. The regression coefficient of instructor-learner interaction was 0.434 with the t-value of 8.088 , which is significant, with the significance level at 0.01 . Like the factor of content feasibility.

Table- II: Correlation analysis result

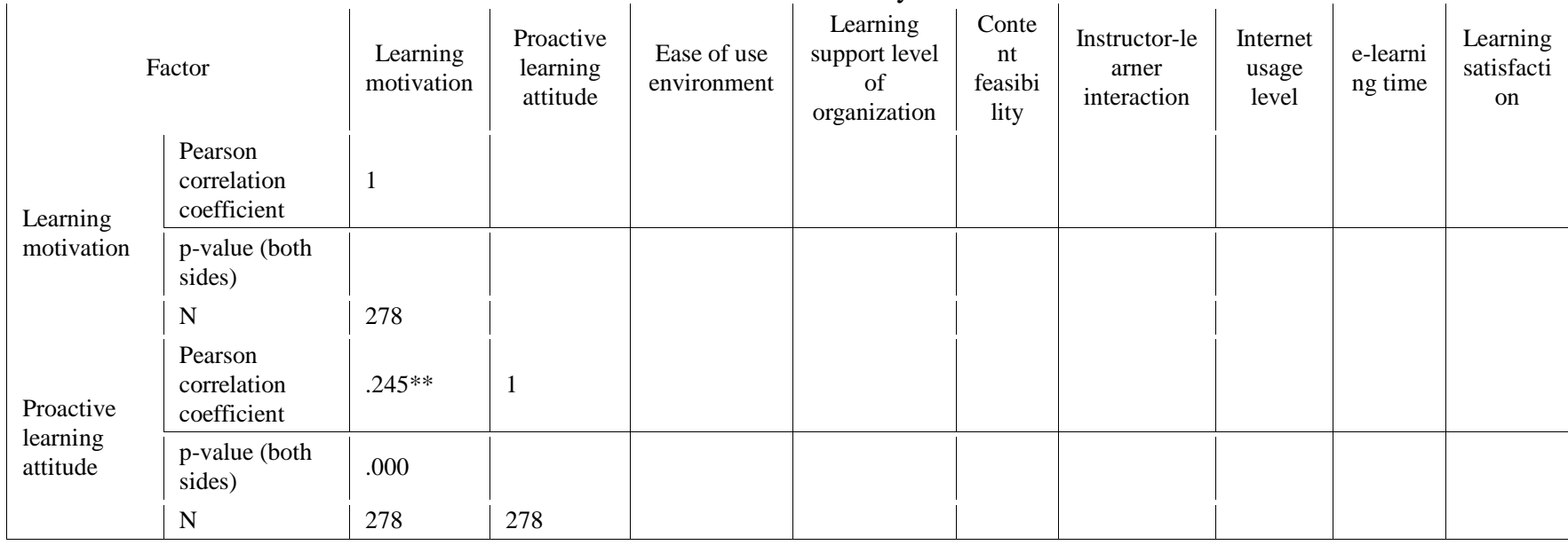


Factors on Learning Satisfaction with a Focus on E-learning in the Military

\begin{tabular}{|c|c|c|c|c|c|c|c|c|c|c|}
\hline \multirow[t]{2}{*}{$\begin{array}{l}\text { Ease of use } \\
\text { environment }\end{array}$} & $\begin{array}{l}\text { Pearson } \\
\text { correlation } \\
\text { coefficient } \\
\text { p-value (both } \\
\text { sides) }\end{array}$ & $\begin{array}{l}.491 * * \\
.000\end{array}$ & $\begin{array}{l}.359 * * \\
.000\end{array}$ & 1 & & & & & & \\
\hline & $\mathrm{N}$ & 278 & 278 & 278 & & & & & & \\
\hline \multirow[t]{2}{*}{$\begin{array}{l}\text { Learning } \\
\text { support } \\
\text { level of } \\
\text { organization }\end{array}$} & $\begin{array}{l}\text { Pearson } \\
\text { correlation } \\
\text { coefficient } \\
\text { p-value (both } \\
\text { sides) }\end{array}$ & $\begin{array}{l}.551^{* *} \\
.000\end{array}$ & $\begin{array}{l}.256^{* *} \\
.000\end{array}$ & $\begin{array}{l}.533 * * \\
.000\end{array}$ & 1 & & & & & \\
\hline & $\mathrm{N}$ & 278 & 278 & 278 & 278 & & & & & \\
\hline \multirow[t]{2}{*}{$\begin{array}{l}\text { Content } \\
\text { feasibility }\end{array}$} & $\begin{array}{l}\text { Pearson } \\
\text { correlation } \\
\text { coefficient } \\
\text { p-value (both } \\
\text { sides) }\end{array}$ & $\begin{array}{l}.537 * * \\
.000\end{array}$ & $\begin{array}{l}.369^{* *} \\
.000\end{array}$ & $\begin{array}{l}.524 * * \\
.000\end{array}$ & $\begin{array}{l}.478^{* *} \\
.000\end{array}$ & 1 & & & & \\
\hline & $\mathrm{N}$ & 278 & 278 & 278 & 278 & 278 & & & & \\
\hline \multirow{3}{*}{$\begin{array}{l}\text { Instructor-le } \\
\text { arner } \\
\text { interaction }\end{array}$} & $\begin{array}{l}\text { Pearson } \\
\text { correlation } \\
\text { coefficient }\end{array}$ & $.559 * *$ & $.327 * *$ & $.618 * *$ & $.608 * *$ & $.685^{* *}$ & 1 & & & \\
\hline & $\begin{array}{l}\text { p-value (both } \\
\text { sides) }\end{array}$ & .000 & .000 & .000 & .000 & .000 & & & & \\
\hline & $\mathrm{N}$ & 278 & 278 & 278 & 278 & 278 & 278 & & & \\
\hline \multirow{3}{*}{$\begin{array}{l}\text { Internet } \\
\text { usage level }\end{array}$} & $\begin{array}{l}\text { Pearson } \\
\text { correlation } \\
\text { coefficient }\end{array}$ & $.123^{*}$ & $.128^{*}$ & $.247 * *$ & .100 & $.167 * *$ & $.181 * *$ & 1 & & \\
\hline & $\begin{array}{l}\text { p-value (both } \\
\text { sides) }\end{array}$ & .041 & .033 & .000 & .097 & .005 & .002 & & & \\
\hline & $\mathrm{N}$ & 278 & 278 & 278 & 278 & 278 & 278 & 278 & & \\
\hline \multirow{3}{*}{$\begin{array}{l}\text { e-learning } \\
\text { time }\end{array}$} & $\begin{array}{l}\text { Pearson } \\
\text { correlation } \\
\text { coefficient }\end{array}$ & $.345^{* *}$ & $.118^{*}$ & $.220 * *$ & $.291 * *$ & $.239 * *$ & $.322 * *$ & .105 & 1 & \\
\hline & $\begin{array}{l}\text { p-value (both } \\
\text { sides) }\end{array}$ & .000 & .049 & .000 & .000 & .000 & .000 & .080 & & \\
\hline & $\mathrm{N}$ & 278 & 278 & 278 & 278 & 278 & 278 & 278 & 278 & \\
\hline \multirow{3}{*}{$\begin{array}{l}\text { Learning } \\
\text { satisfaction }\end{array}$} & $\begin{array}{l}\text { Pearson } \\
\text { correlation } \\
\text { coefficient }\end{array}$ & $.632 * *$ & $.313 * *$ & $.625 * *$ & $.635^{* *}$ & $.654 * *$ & $.787 * *$ & $.216^{* *}$ & $.315^{* *}$ & 1 \\
\hline & $\begin{array}{l}\text { p-value (both } \\
\text { sides) }\end{array}$ & .000 & .000 & .000 & .000 & .000 & .000 & .000 & .000 & \\
\hline & $\mathrm{N}$ & 278 & 278 & 278 & 278 & 278 & 278 & 278 & 278 & 278 \\
\hline
\end{tabular}

Table- III: Multiple regression analysis result

\begin{tabular}{|c|c|c|c|c|c|c|c|c|}
\hline \multirow{2}{*}{\multicolumn{2}{|c|}{ Classification }} & \multicolumn{2}{|c|}{ U Coefficients } & \multirow{2}{*}{$\begin{array}{l}\text { SC } \\
\text { beta }\end{array}$} & \multirow{2}{*}{$\mathbf{t}$} & \multirow{2}{*}{$\begin{array}{l}\text { p-va } \\
\text { lue }\end{array}$} & \multicolumn{2}{|c|}{$\begin{array}{l}\text { Collinearity } \\
\text { statistics }\end{array}$} \\
\hline & & B & $\begin{array}{c}S \\
\text { error }\end{array}$ & & & & $\mathbf{T}$ & VIF \\
\hline \multicolumn{2}{|c|}{ (Constant) } & $\begin{array}{c}-.37 \\
8\end{array}$ & .221 & & $\begin{array}{c}-1.71 \\
0\end{array}$ & .088 & & \\
\hline \multirow{3}{*}{ Learner } & $\begin{array}{l}\text { Learning } \\
\text { motivatio } \\
\mathrm{n}\end{array}$ & .153 & .038 & .178 & 4.030 & .000 & $\begin{array}{c}.55 \\
3\end{array}$ & 1.810 \\
\hline & $\begin{array}{l}\text { Proactive } \\
\text { learning } \\
\text { attitude }\end{array}$ & $\begin{array}{c}-.00 \\
6\end{array}$ & .038 & -.006 & -.153 & .879 & $\begin{array}{c}.81 \\
7\end{array}$ & 1.224 \\
\hline & $\begin{array}{l}\text { Internet } \\
\text { usage } \\
\text { level }\end{array}$ & .053 & .040 & .047 & 1.321 & .187 & $\begin{array}{c}.86 \\
0\end{array}$ & 1.163 \\
\hline \multirow{2}{*}{$\begin{array}{l}\text { Learning } \\
\text { environm } \\
\text { ent }\end{array}$} & $\begin{array}{l}\text { Ease of } \\
\text { use } \\
\text { environm } \\
\text { ent }\end{array}$ & .116 & .048 & .110 & 2.410 & .017 & $\begin{array}{l}.51 \\
7\end{array}$ & 1.936 \\
\hline & $\begin{array}{l}\text { Learning } \\
\text { support }\end{array}$ & .154 & .046 & .149 & 3.335 & .001 & $\begin{array}{c}.53 \\
9\end{array}$ & 1.855 \\
\hline
\end{tabular}

\begin{tabular}{|c|c|c|c|c|c|c|c|c|}
\hline & $\begin{array}{l}\text { level } \\
\text { from } \\
\text { organizat } \\
\text { ion }\end{array}$ & & & & & & & \\
\hline \multirow{2}{*}{$\begin{array}{l}\text { Instructio } \\
\text { nal } \\
\text { design }\end{array}$} & $\begin{array}{l}\text { Feasibilit } \\
\text { y of } \\
\text { content }\end{array}$ & .140 & .054 & .125 & 2.592 & .010 & $\begin{array}{c}.46 \\
4\end{array}$ & 2.155 \\
\hline & $\begin{array}{l}\text { Instructo } \\
\text { r-learner } \\
\text { interactio } \\
\mathrm{n}\end{array}$ & .445 & .055 & .434 & 8.088 & .000 & $\begin{array}{c}.37 \\
3\end{array}$ & 2.679 \\
\hline \multicolumn{2}{|c|}{ e-learning time } & .015 & .039 & .014 & .394 & .694 & $\begin{array}{c}.83 \\
9\end{array}$ & 1.191 \\
\hline \multicolumn{2}{|c|}{ Age group } & .071 & .070 & .062 & 1.006 & .316 & $\begin{array}{c}.28 \\
6\end{array}$ & 3.501 \\
\hline \multicolumn{2}{|c|}{ Education level } & .039 & .032 & .043 & 1.210 & .227 & $\begin{array}{c}.85 \\
5\end{array}$ & 1.169 \\
\hline \multicolumn{2}{|c|}{ Years of service } & $\begin{array}{c}-.05 \\
0\end{array}$ & .055 & -.054 & -.905 & .366 & $\begin{array}{c}.29 \\
8\end{array}$ & 3.350 \\
\hline
\end{tabular}

Published By:

Blue Eyes Intelligence Engineering

\& Sciences Publication

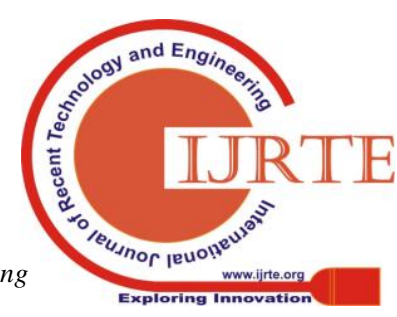


R 0.845a, R square 0.714, Durbin-Watson 1.880, F 60.471, N 278

U Coefficients : Unstandardized Coefficients

SC : Standardized Coefficients

S. error : Standard error

$\mathrm{T}$ : Tolerance

\section{CONCLUSION}

The findings of this study showed the following factors as positively affecting learning satisfaction with e-learning in the military: learning motivation, ease of the use environment, learning support level of the organization, content feasibility, and instructor-learner interaction. Similarly with the official education centers and universities, learning motivation was proven to be the most important factor in e-learning education in the military.

Also, as factors that reflect the nature of the military, ease of the use environment and learning support level of the organization were identified as factors that affect learning satisfaction. This result suggests the importance of the infrastructure and setting for e-learning in the military. The factors of content feasibility and infrastructure-learner interaction were also shown to affect learning satisfaction, suggesting further investment in the design and development of e-learning contents and an increased proactiveness of the instructors to improve learning satisfaction.

This study only verified the factors affecting learning satisfaction by partially modifying the measuring instruments used in previous studies and subjects. As such, further studies are needed that examine the learning satisfaction factors while considering the nature of the military. The national defense sector offers e-learning by military unit, but the system activities are inadequate. An integrated e-learning system should be built for national defense to offer integrated learning programs and professional development for the armed forces. Also, system improvements, better convenience, content quality enhancement, better learning conditions, and learning motivation should be considered to enhance the learning satisfaction with e-learning in the military.

\section{REFERENCES}

1. Gloria C. Alaneme, Peter O. Olayiwola, Comfort O. Reju, "Combining traditional learning and the e-learning methods in higher distance education: Assessing learners' preference" in 2010 4th International Conference on Distance Learning and Education, San Juan, PR, USA https://doi.org/10.1109/ICDLE.2010.5606008

2. Michael Leyer, Jürgen Moormann, Minhong Wang, "Is Learning-by-Doing via E-learning Helpful to Gain Generic Process Knowledge?" 2014 IEEE 14th International Conference on Advanced Learning Technologies, Athens, Greece, https://doi.org/10.1109/ICALT.2014.206

3. Rachael Gallagher, "Design technology" Electronics Education., 26 27, 1991. https://doi.org/10.1049/ee.1991.0026

4. Garrison, D. R. \& Anderson, T. E-Learning in the 21 st Century: "A Framework for Research and Practice", Taylor \& Francis, New York. 2003.

5. Sun-Ok Park, Geunjoo Lee. "Analysis of the Determinants of Satisfaction on Cyber Education for Centeral Official Education Institute." Journal of Korean society and public administration, 2012. Vol. 23 No. 1, pp. 167-182.

6. Davis F. D. "Perceived Usefulness, Perceived Ease of Use, and User Acceptance of Information Technology." MIS Quartly, 1989. Vol. 13, pp. 319-340.

7. Chih-Ming Chen, Ting-Chun Huang, Tai-Hung Li, Chia-Meng Huang, "Personalized E-Learning System with Self-Regulated Learning Assisted Mechanisms for Promoting Learning Performance" Seventh
IEEE International Conference on Advanced Learning Technologies, 2007, . https://doi.org/10.1109/ICALT.2007.205

8. B. Wolman. Dictionary of behavioral science. SD Academic press. 1989. pp. 28.

9. Gloria C. Alaneme, Peter O. Olayiwola, Comfort O. Reju, "Combining traditional learning and the e-learning methods in higher distance education: Assessing learners' preference" International Conference on Distance Learning and Education, San Juan, PR, USA, 187 - 190, 2010, https://doi.org/ 10.1109/ICDLE.2010.5606008

10. Bailey, J.E. \& Pearson, S.W. "Development of a tool for measuring and analyzing computer user satisfaction.” Management science. 1983. 29, pp.530-545.

\section{AUTHORS PROFILE}

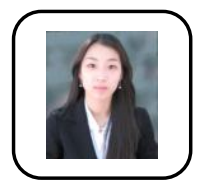

CHUN YANGHA Ph.D. in Soongsil University in 2016. She is currently a professor in the Department of Computer Science, Yongin University, and is a project evaluator for companies and various organizations.

Areas of interest include big data analytics, cloud computing, and system algorithms, network data security. She is also working on several projects on network security. 